\title{
Effect of Nitrogen and Potash Levels on Green Pod Yield, Quality and Post- harvest Soil Nutrient Status of Okra (Abelmoschus esculentus L. Moench) during kharif Season under Middle Gujarat Conditions
}

\author{
Jaymin G. Chudhari, S.N.Shah, H. K. Patel* and J.C. Shroff \\ Department of Agronomy, B.A.College of Agriculture, Anand Agricultural University, \\ Anand-388110 (Gujarat), India \\ *Corresponding author
}

\begin{tabular}{|l|}
\hline \multicolumn{1}{|l}{} \\
\hline Ke y w o r d s \\
Green pod yield, \\
Nitrogen, Potash \\
and protein \\
\hline Article Info \\
\hline $\begin{array}{l}\text { Accepted: } \\
15 \text { April } 2020 \\
\text { Available Online: } \\
10 \text { May } 2020\end{array}$ \\
\hline \hline
\end{tabular}

\section{A B S T R A C T}

The field experiment was conducted at Main Vegetable Research Station, Anand Agricultural University, Anand to study the "Effect of nitrogen and potash levels on growth and green pod yield of okra (Abelmoschus esculentus L. Moench) during kharif season under middle Gujarat conditions" during the year 2015. The soil of experimental field was loamy sand in texture having good drainage and $7.7 \mathrm{pH}$ at $0-15 \mathrm{~cm}$ soil depth. The experiment was laid out in RBD with factorial concept in three replications. The treatment comprised of four nitrogen levels $(75,100,125$ and $150 \mathrm{~kg} \mathrm{~N} / \mathrm{ha}$ ) and five levels of potash $(25,50,75,25 \mathrm{as}$ basal +25 at $45 \mathrm{DAS}$ and 37.5 as basal +37.5 at $45 \mathrm{DAS} \mathrm{kg}$ $\mathrm{K}_{2} \mathrm{O} /$ ha). There were total twenty treatment combinations of different levels of nitrogen and potash. The crop was fertilized as per respective nitrogen @ 75,100,125 and $150 \mathrm{~kg}$ $\mathrm{N} / \mathrm{ha}$ and potash@25,50,75, 50 and $75 \mathrm{~kg} \mathrm{~K}_{2} \mathrm{O} / \mathrm{ha}$ in the respective plots as per treatments. Results revealed that application of $150 \mathrm{~kg} \mathrm{~N} / \mathrm{ha}$ recorded significantly higher green pod yield, available nitrogen and nitrogen content. Application of potash in two equal split ( $37.5 \mathrm{~kg} \mathrm{~K}_{2} \mathrm{O} / \mathrm{ha}$ at basal $+37.5 \mathrm{~kg} \mathrm{~K}_{2} \mathrm{O} / \mathrm{ha}$ at $45 \mathrm{DAS}$ ) treatment recorded higher green pod yield as well as various quality parameters, available potash in soil and potash content in green fruit. In case of cost of cultivation, result revealed that application of $125 \mathrm{~kg} \mathrm{~N} / \mathrm{ha}$ with two equal split of $25 \mathrm{~kg} \mathrm{~K}_{2} \mathrm{O} / \mathrm{ha}$ at basal $+25 \mathrm{~kg} \mathrm{~K}_{2} \mathrm{O} / \mathrm{ha}$ at 45 day treatment combination recorded higher benefit cost ratio. In case of individual treatment on economics, application of $150 \mathrm{~kg} \mathrm{~N} / \mathrm{ha}$ and potash application $(37.5 \mathrm{~kg} \mathrm{~K} 2 \mathrm{O} / \mathrm{ha}$ at basal $+37.5 \mathrm{~kg} \mathrm{~K}_{2} \mathrm{O} / \mathrm{ha}$ at $45 \mathrm{DAS}$ ) was recorded higher benefit cost ratio.

\section{Introduction}

Okra (Abelmoschus esculentus L. Moench) is a member under Malvaceae family and is also known as Lady's finger. It is an annual vegetable crop grown from seed in tropical and sub-tropical parts of the world.

Okra produces fruit for a longer time and needs a balanced and sufficient supply of nutrients for higher yield and better quality. Vegetables and vegetable based cropping system show that vegetable crops are well responsive to nutrient supply through organic manures and chemical fertilizers. It is well proved that growth, yield and quality of plants are greatly influenced by availability of a 
wide range of nutrients in the soil. Nitrogen is an essential macronutrient which has great significance in growth, development and metabolism of plants. Phosphorus is a constituent of nucleic acid, phospholipids and several enzymes which are of great importance in the transformation of energy within the plant system, metabolism and also in respiration in plants. It has beneficial effect on root development, growth and also hastens maturity as well as improves quality of crop produce. Potassium is one of the three major nutrient elements $(\mathrm{N}, \mathrm{P}$ and $\mathrm{K}$ ) required by plants. Potassium imparts vigour and disease resistance to the plant and plays an important role in crop productivity. Plant health at field is also responsible for lower productivity and need to look for other means in production system management which could help in achieving high yield and productivity.

Little information is available on the interaction effect of nitrogen and potash on green pod yield and quality of okra, Hence keeping in view and importance of nitrogen and potash such experiment "Effect of nitrogen and potash levels on growth and green pod yield of okra (Abelmoschus esculentus L. Moench)" was carried out Anand Agricultural University, Anand.

\section{Materials and Methods}

The field experiment was conducted at Main Vegetable Research Station, Anand Agricultural University, Anand to study the "Effect of nitrogen and potash levels on growth and green pod yield of okra (Abelmoschus esculentus L. Moench) during kharif season under middle Gujarat conditions" during the year 2015. The soil of experimental field was loamy sand in texture having good drainage and $7.7 \mathrm{pH}$ at $0-15 \mathrm{~cm}$ soil depth. The treatment comprised of four nitrogen levels $(75,100,125$ and $150 \mathrm{~kg}$ $\mathrm{N} / \mathrm{ha})$ and five levels of potash $(25,50,75,25$ as basal + 25 at 45 DAS and 37.5 as basal + 37.5 at $45 \mathrm{DAS} \mathrm{kg} \mathrm{K}_{2} \mathrm{O} / \mathrm{ha}$ ). Experiment laid down in Randomized Block Design with three replication. There were total twenty treatment combinations of levels of nitrogen and potash. The crop was fertilized as per respective nitrogen@75,100,125 and $150 \mathrm{~kg} \mathrm{~N} / \mathrm{ha}$ and potash@ 25, 50, 75, 50 and $75 \mathrm{~kg} \mathrm{K2O/ha} \mathrm{in}$ the respective plots as per treatments. The $25 \%$ quantity of nitrogen was given as a basal dose at the time of preparation of land and remaining quantities was applied as top dressing at around 30, 45 and 60 days after sowing. Entire quantity of phosphorus (50 $\mathrm{kg} / \mathrm{ha}$ ) were applied as a common basal dose in furrow to all the plots in form of single super phosphate. The furrows were lightly covered with soil. The seeds of GAO-5 variety of okra were dibbled in previously opened furrows at a distance of $60 \mathrm{~cm}$ between and $30 \mathrm{~cm}$ within the row. The biometric observations were recorded from five randomly selected plants tagged in each net plot. The details of various growth parameters, yield attributes and chemical parameters studied during the course of investigation. The soil samples were collected after completion of crop. The chemical analysis for pod and soil samples carried out by various standard methods of chemical analyses.

An analysis of available nitrogen by (Alkaline Permanganate method) available phosphorus by (Colorimetric method) and Estimation of potassium was made from acid extract by Flame photometer method as described by Jackson (1973).

The data were analyzed individually as peer the standard analysis of variance ANOVA technique using the Randomized Block Design (Factorial). The treatment comparisons were made using t test at $\mathrm{P}=0.05$ level of significance. 


\section{Results and Discussion}

\section{Effect of nitrogen}

The results in respect of green pod yield (Table-1) revealed that nitrogen levels had pronounced effect on green pod yield. Nitrogen application @ $150 \mathrm{~kg} / \mathrm{ha}\left(\mathrm{N}_{4}\right)$ produced significantly higher green pod yield $(147.31 \mathrm{q} / \mathrm{ha})$. The lowest green pod yield $(73.02 \mathrm{q} / \mathrm{ha}$ ) was recorded under application of $75 \mathrm{~kg} \mathrm{~N} / \mathrm{ha}\left(\mathrm{N}_{1}\right)$. The increase in green pod yield was recorded under treatment $\mathrm{N}_{4}$ was 64.15 per cent over treatment $\mathrm{N}_{1}$. More green pod yield at higher dose of nitrogen was due to more vegetative growth resulting from efficient utilization of nutrients, water, radiation and increased metabolic activities followed by increased translocation toward yield contributing characters These results are in conformity with findings of those reported by Shanke et al., (2003), Suthar et al., (2009), Singh et al., (2012) and Deepika et al., (2015).

In the study, different nitrogen levels do not showed their significant influence on moisture and mucilage content (Table-1) in okra fruit but the total chlorophyll content in okra fruit remained significant (Table-1). Significantly higher total chlorophyll content $(1.67 \mathrm{mg} / \mathrm{g})$ in okra fruit was recorded under treatment $\mathrm{N}_{4}$ $\left(150 \mathrm{~kg} \mathrm{~N} \mathrm{ha}^{-1}\right)$ as compared to rest of the treatments. It might be due to nitrogen as the constitute of chlorophyll content and the synthesis of amino acid, protein and chlorophyll is accelerated with the greater nitrogen supply. These results are in conformity with the findings of Paliwal et al., (1999).

Different nitrogen levels do not showed their significant influence on organic carbon, available phosphorus and potassium status (Table 1) in soil after harvesting of crop but the available nitrogen in soil after harvesting of crop remained significant. (Table-1). An application of nitrogen brought out nonsignificant variation in phosphorus and potash content in plant (Table-1) but the nitrogen content in plant remained significant (Table1). The significantly the higher nitrogen content $(275.96 \mathrm{~kg} / \mathrm{ha})$ in plant was recorded under the treatment $\mathrm{N}_{4}(150 \mathrm{~kg} / \mathrm{ha})$. However, it was at par with treatment $\mathrm{N}_{3}(125$ $\mathrm{kg} / \mathrm{ha}$ ).Increase in nitrogen content under treatment $\mathrm{N}_{4}$ could be due to more quantity of nitrogen application enhanced green fruit yield and ultimately helped in increase of nitrogen content in plant.

\section{Effect of potash}

Significantly the higher green pod yield of okra was recorded under treatment $\mathrm{K}_{5}$ (37.5 $\mathrm{kg} \mathrm{K}_{2} \mathrm{O} / \mathrm{ha}$ at basal $+37.5 \mathrm{~kg} \mathrm{~K}_{2} \mathrm{O} / \mathrm{ha}$ at 45 DAS). (Table-1) However, it was at par with treatment $\mathrm{K}_{4}\left(25 \mathrm{~kg} \mathrm{~K} \mathrm{~K}_{2} \mathrm{O} / \mathrm{ha}\right.$ at basal $+25 \mathrm{~kg}$ $\mathrm{K}_{2} \mathrm{O} / \mathrm{ha}$ at 45 DAS) and treatment $\mathrm{K}_{3}(75 \mathrm{~kg}$ $\mathrm{K}_{2} \mathrm{O} / \mathrm{ha}$ ) in different picking. Treatment $\mathrm{K}_{1}$ registered significantly the lowest green pod yield $\left(101.54 \mathrm{q} \mathrm{ha}^{-1}\right)$. This show that there was a significant improvement in growth and yield attributes due to split application potash was probably due to better translocation and partitioning of assimilates toward the sink at proper doses of potash. In fact potash application is known to improve the physiological and metabolic processes and translocation resulted in increased growth and yield attributes and there by increased green pod yield. The finding on higher green pod yields due to different levels of potash were also reported by Khan et al., (2014), Mushtaq et al., (2014) and Pushpavalli et al., (2014).

In the study, different potash levels showed their significant influence on total chlorophyll content and mucilage content (Table 1) in okra fruit. Significantly higher total chlorophyll content and mucilage content in okra fruit was recorded under treatment 
$\mathrm{K}_{5}(37.5 \mathrm{~kg} \mathrm{~K} 2 \mathrm{O} / \mathrm{ha}$ at basal $+37.5 \mathrm{~kg} \mathrm{~K} 2 \mathrm{O} / \mathrm{ha}$ at 45 DAS). However, it was at par with treatment $\mathrm{K}_{4}(25 \mathrm{~kg} \mathrm{~K} 2 \mathrm{O} / \mathrm{ha}$ at basal $+25 \mathrm{~kg}$ $\mathrm{K}_{2} \mathrm{O} /$ haat 45 DAS). It might be due to potash increase the photosynthesis and enzymatic activities in plant. The results are confirmed by finding of Deepika et al., (2015).

In the study, different levels of potash did not show any significant influence on organic carbon, available nitrogen and available phosphorus in soil after harvest of okra. While, significant influence due to potash application on $\mathrm{K}$ status of soil after the harvesting of crop. Significantly the highest K status of soil $(260.20 \mathrm{~kg} / \mathrm{ha})$ after harvest was recorded under the treatment $\mathrm{K}_{5}(37.5 \mathrm{~kg}$ $\mathrm{K}_{2} \mathrm{O} / \mathrm{ha}$ at basal $+37.5 \mathrm{~kg} \mathrm{~K}_{2} \mathrm{O} / \mathrm{ha}$ at 45 DAS). Potash content in plant (Table-1) was influence significantly due to potash evels. Increase in potash content under treatment $\mathrm{K}_{5}$ could be due to split application of potash enhanced potash availability at later stage of growth and ultimately increasedgreen fruit yield (Table-1) and helped in increase of potash content in plant.

\section{Interaction effect}

The results presented in Table- 2 revealed that significantly higher green pod yield was recorded under treatment combination $\mathrm{N}_{4} \mathrm{~K}_{5}(167.45 \mathrm{q} / \mathrm{ha})$ as compared to rest of the treatment combinations but it was at par with treatment combinations $\mathrm{N}_{4} \mathrm{~K}_{4}, \quad \mathrm{~N}_{4} \mathrm{~K}_{3}, \quad \mathrm{~N}_{3} \mathrm{~K}_{5}$, $\mathrm{N}_{3} \mathrm{~K}_{4}$ and $\mathrm{N}_{3} \mathrm{~K}_{3}$. The higher green pod yield under treatment combination $\mathrm{N}_{4} \mathrm{~K}_{5}$ might be due to synergic interactive effect of nitrogen and potash levels. This might be due to interactive effect of nitrogen and potash levels of greener pod yield at higher dose of nitrogen and potash was due to more vegetative growth resulting from efficient utilization of nutrient, water, radiation and increased metabolic activities followed by increased translocation toward yield contribution characteristics. Also potash application improve physiological and metabolic process and translocation resulted in increased growth and yield attributes and there by increased green pod yield in okra were also reported by Mani and Ramanathan (1980).

\section{Economics}

\section{Effect of nitrogen levels}

The results pertaining to benefit: cost analysis of the crop as influenced by nitrogen levels (Table-3) indicated that increased net realization with increase nitrogen levels. Application of $150 \mathrm{~kg} \mathrm{~N} / \mathrm{ha}\left(\mathrm{N}_{4}\right)$ registered maximum net realization (232731/ha) with BCR value of 3.76 , application of $125 \mathrm{~kg}$ $\mathrm{N} / \mathrm{ha}\left(\mathrm{N}_{3}\right)$ recorded $227137 /$ ha net profit with the BCR of 3.69. The lowest net realization $85130 /$ ha was noticed under application of 75 $\mathrm{kg} \mathrm{N} / \mathrm{ha}\left(\mathrm{N}_{1}\right)$ with $1.39 \mathrm{BCR}$ value. The increased net realization with increasing levels of nitrogen was due to increased growth and yield attributing characters and ultimately green pod yield (Table-4). The similar results were reported by Firoz (2009) and Suthar (2009).

\section{Effect of potash levels}

Data presented in Table 3 revealed that maximum net realization was occurred under treatment $\mathrm{K}_{5}\left(37.5 \mathrm{~kg} \mathrm{~K} \mathrm{~K}_{2} \mathrm{O} / \mathrm{ha}\right.$ at basal +37.5 $\mathrm{kg} \mathrm{K}_{2} \mathrm{O} / \mathrm{ha}$ at $45 \mathrm{DAS}$ ). (203149/ha) with the highest BCR value of 3.27 followed by K4 treatment with 199915/ ha net realization and 3.25 BCR value.

The lowest net realization (142442/ha) was recorded under the treatment $\mathrm{K}_{1}$ with 2.35 $\mathrm{BCR}$ value. The higher net realization under treatment $\mathrm{K}_{5}$ was only due to higher green pod yield. 
Table.1 Yield, quality, soil and pod nutrient status as influenced by different treatments

\begin{tabular}{|c|c|c|c|c|c|c|c|c|c|c|c|}
\hline Treatment & $\begin{array}{c}\text { Green } \\
\text { pod } \\
\text { yield } \\
\text { (q/ha) }\end{array}$ & $\begin{array}{c}\text { Moisture } \\
(\%)\end{array}$ & $\begin{array}{c}\text { Total } \\
\text { chlorophyll } \\
\text { content } \\
\text { (mg/g) }\end{array}$ & $\begin{array}{c}\text { Mucilage } \\
\text { (mg/g) }\end{array}$ & $\begin{array}{c}\text { Organic } \\
\text { carbon } \\
(\%)\end{array}$ & $\begin{array}{c}\text { Available } \\
\text { nitrogen } \\
\text { (kg/ha) }\end{array}$ & $\begin{array}{c}\text { Available } \\
\text { phosphorus } \\
\text { (kg/ha) }\end{array}$ & $\begin{array}{c}\text { Available } \\
\text { potassium } \\
\text { (kg/ha) }\end{array}$ & $\begin{array}{c}\mathrm{N} \\
\text { content } \\
(\%)\end{array}$ & $\begin{array}{c}P \\
\text { content } \\
(\%)\end{array}$ & $\begin{array}{c}\text { K } \\
\text { content } \\
(\%)\end{array}$ \\
\hline \multicolumn{12}{|c|}{ Nitrogen level (kg/ha) } \\
\hline $\mathbf{N}_{1}$ & 73.02 & 80.07 & 1.29 & 232.76 & 0.46 & 238.11 & 42.15 & 240.41 & 1.05 & 0.49 & 1.35 \\
\hline $\mathbf{N}_{2}$ & 114.80 & 80.59 & 1.44 & 233.65 & 0.46 & 256.00 & 43.93 & 240.74 & 1.18 & 0.50 & 1.38 \\
\hline $\mathbf{N}_{3}$ & 144.35 & 81.17 & 1.61 & 235.68 & 0.47 & 270.08 & 46.57 & 246.03 & 1.42 & 0.51 & 1.45 \\
\hline $\mathbf{N}_{4}$ & 147.31 & 82.07 & 1.67 & 236.16 & 0.47 & 275.96 & 46.69 & 250.45 & 1.52 & 0.51 & 1.49 \\
\hline SEm \pm & 3.41 & 0.84 & 0.02 & 2.28 & 0.01 & 6.13 & 1.58 & 3.44 & 0.03 & 0.01 & 0.05 \\
\hline $\begin{array}{l}\text { CD } \\
(P=0.05)\end{array}$ & 9.77 & NS & 0.06 & NS & NS & 17.55 & NS & NS & 0.11 & NS & NS \\
\hline \multicolumn{12}{|c|}{ Potash level (kg/ha) } \\
\hline $\mathbf{K}_{1}$ & 101.54 & 79.69 & 1.37 & 227.62 & 0.45 & 254.46 & 43.15 & 232.15 & 1.22 & 0.48 & 1.23 \\
\hline $\mathbf{K}_{2}$ & 108.83 & 80.35 & 1.47 & 229.34 & 0.46 & 256.62 & 43.93 & 238.15 & 1.27 & 0.50 & 1.32 \\
\hline $\mathbf{K}_{3}$ & 125.79 & 81.20 & 1.53 & 236.01 & 0.47 & 261.78 & 45.10 & 243.09 & 1.32 & 0.51 & 1.46 \\
\hline $\mathbf{K}_{4}$ & 130.60 & 81.70 & 1.54 & 237.20 & 0.46 & 257.77 & 44.50 & 242.19 & 1.30 & 0.50 & 1.48 \\
\hline $\mathbf{K}_{5}$ & 132.59 & 81.93 & 1.59 & 242.64 & 0.47 & 269.56 & 46.26 & 260.20 & 1.34 & 0.52 & 1.59 \\
\hline SEm \pm & 3.82 & 0.95 & 0.02 & 2.55 & 0.01 & 6.85 & 1.76 & 3.84 & 0.04 & 0.008 & 0.04 \\
\hline $\begin{array}{l}\text { CD } \\
(P=0.05)\end{array}$ & 10.92 & NS & 0.07 & 7.30 & NS & NS & NS & 11.00 & NS & NS & 0.14 \\
\hline $\mathbf{N} \times \mathbf{K}$ & Sig. & NS & NS & NS & NS & NS & NS & NS & NS & NS & NS \\
\hline CV \% & 11.02 & 4.06 & 5.54 & 3.76 & 8.66 & 9.13 & 13.67 & 5.45 & 5.53 & 5.85 & 5.54 \\
\hline
\end{tabular}


Table. 2 Green pod yield as influenced by Nitrogen X potash interaction

\begin{tabular}{|c|c|c|c|c|c|}
\hline \multirow{2}{*}{ Treatment } & \multicolumn{5}{|c|}{ Green pod yield (q/ha) } \\
\cline { 2 - 6 } & \multicolumn{5}{|c|}{ Potash levels (kg/ha) } \\
\hline & $\mathrm{K}_{1}$ & $\mathrm{~K}_{2}$ & $\mathrm{~K}_{3}$ & $\mathrm{~K}_{4}$ & $\mathrm{~K}_{5}$ \\
\hline $\mathbf{N}_{\mathbf{1}}$ & 65.82 & 71.01 & 75.04 & 74.44 & 78.76 \\
\hline $\mathbf{N}_{\mathbf{2}}$ & 108.50 & 114.27 & 115.01 & 117.41 & 118.79 \\
\hline $\mathbf{N}_{\mathbf{3}}$ & 114.71 & 123.93 & 152.59 & 165.15 & 165.35 \\
\hline $\mathbf{N}_{\mathbf{4}}$ & 117.131 & 126.08 & 160.48 & 165.39 & 167.45 \\
\hline $\mathbf{S E m} \pm$ & & & 7.63 & & \\
\hline $\mathbf{C D}(\mathbf{P}=\mathbf{0 . 0 5})$ & & & 21.84 & \\
\hline $\mathbf{C V} \%$ & & & 11.02 \\
\end{tabular}

Table.3 Economics as influenced by different levels of nitrogen and potash levels

\begin{tabular}{|c|c|c|c|c|c|c|c|}
\hline Treatment & $\begin{array}{l}\text { Green } \\
\text { pod yield } \\
\text { (q/ha) }\end{array}$ & $\begin{array}{l}\text { Cost of } \\
\text { treatment } \\
(\mathrm{Rs} / \mathrm{ha})\end{array}$ & $\begin{array}{c}\text { Common } \\
\text { cost } \\
(\mathbf{R s} / \mathbf{h a})\end{array}$ & $\begin{array}{l}\text { Total } \\
\text { cost } \\
(\text { Rs/ha) }\end{array}$ & $\begin{array}{c}\text { Gross } \\
\text { realization } \\
\text { (Rs/ha) }\end{array}$ & $\begin{array}{l}\text { Net } \\
\text { realization } \\
(\text { Rs/ha) }\end{array}$ & BCR \\
\hline \multicolumn{8}{|c|}{ Nitrogen levels (kg/ha) } \\
\hline$N_{1}=75$ & 73 & 1128 & 59783 & 60911 & 146041 & 85130 & 1.39 \\
\hline$N_{2}=100$ & 115 & 1454 & 59783 & 61237 & 229606 & 168369 & 2.75 \\
\hline$N_{3}=125$ & 144 & 1780 & 59783 & 61563 & 288700 & 227137 & 3.69 \\
\hline$N_{4}=150$ & 147 & 2106 & 59783 & 61889 & 294620 & 232731 & 3.76 \\
\hline \multicolumn{8}{|l|}{ Potash levels (kg/ha) } \\
\hline$K_{1}=25$ & 102 & 855 & 59783 & 60638 & 203080 & 142442 & 2.34 \\
\hline $\mathbf{K}_{2}=\mathbf{5 0}$ & 109 & 1542 & 59783 & 61325 & 217660 & 156335 & 2.54 \\
\hline$K_{3}=75$ & 126 & 2248 & 59783 & 62031 & 251580 & 189549 & 3.05 \\
\hline $\begin{array}{r}K_{4}=25 \text { at basal+ } \\
25 \text { at } 45 \text { DAS }\end{array}$ & 131 & 1542 & 59783 & 61325 & 261240 & 199915 & 3.25 \\
\hline $\begin{array}{c}K_{5}=37.5 \text { at basal }+ \\
37.5 \text { at } 45 \\
\text { DAS }\end{array}$ & 133 & 2248 & 59783 & 62031 & 265180 & 203149 & 3.27 \\
\hline
\end{tabular}


Table.4 Economics of different treatment combinations

\begin{tabular}{|l|c|c|c|c|c|}
\hline Treatment & $\begin{array}{c}\text { Green } \\
\text { pod yield } \\
\text { (q/ha) }\end{array}$ & $\begin{array}{c}\text { Cost of } \\
\text { cultivation } \\
\text { (Rs/ha) }\end{array}$ & $\begin{array}{c}\text { Gross } \\
\text { realization } \\
\text { (Rs/ha) }\end{array}$ & $\begin{array}{c}\text { Net } \\
\text { realization } \\
\text { (Rs/ha) }\end{array}$ & BCR \\
\hline $\mathbf{N}_{\mathbf{1}} \mathbf{K}_{\mathbf{1}}$ & 66 & 61766 & 131652 & 69886 & 1.13 \\
\hline $\mathbf{N}_{\mathbf{1}} \mathbf{K}_{\mathbf{2}}$ & 71 & 62453 & 142035 & 79582 & 1.27 \\
\hline $\mathbf{N}_{\mathbf{1}} \mathbf{K}_{\mathbf{3}}$ & 75 & 63159 & 150095 & 86936 & 1.38 \\
\hline $\mathbf{N}_{\mathbf{1}} \mathbf{K}_{\mathbf{4}}$ & 74 & 62453 & 148897 & 86444 & 1.38 \\
\hline $\mathbf{N}_{\mathbf{1}} \mathbf{K}_{\mathbf{5}}$ & 79 & 63159 & 157528 & 94369 & 1.49 \\
\hline $\mathbf{N}_{\mathbf{2}} \mathbf{K}_{\mathbf{1}}$ & 109 & 62092 & 217010 & 154918 & 2.49 \\
\hline $\mathbf{N}_{\mathbf{2}} \mathbf{K}_{\mathbf{2}}$ & 114 & 62779 & 228556 & 165777 & 2.64 \\
\hline $\mathbf{N}_{\mathbf{2}} \mathbf{K}_{\mathbf{3}}$ & 115 & 63485 & 230028 & 166544 & 2.62 \\
\hline $\mathbf{N}_{\mathbf{2}} \mathbf{K}_{\mathbf{4}}$ & 117 & 62779 & 234839 & 172061 & 2.74 \\
\hline $\mathbf{N}_{\mathbf{2}} \mathbf{K}_{\mathbf{5}}$ & 119 & 63485 & 237593 & 1741078 & 2.74 \\
\hline $\mathbf{N}_{\mathbf{3}} \mathbf{K}_{\mathbf{1}}$ & 115 & 62418 & 229420 & 167002 & 2.68 \\
\hline $\mathbf{N}_{\mathbf{3}} \mathbf{K}_{\mathbf{2}}$ & 124 & 63105 & 247877 & 184772 & 2.93 \\
\hline $\mathbf{N}_{\mathbf{3}} \mathbf{K}_{\mathbf{3}}$ & 153 & 63811 & 305186 & 241375 & 3.78 \\
\hline $\mathbf{N}_{\mathbf{3}} \mathbf{K}_{\mathbf{4}}$ & 165 & 63105 & 330300 & 267195 & 4.23 \\
\hline $\mathbf{N}_{\mathbf{3}} \mathbf{K}_{\mathbf{5}}$ & 165 & 63811 & 330700 & 266889 & 4.18 \\
\hline $\mathbf{N}_{\mathbf{4}} \mathbf{K}_{\mathbf{1}}$ & 117 & 62744 & 234260 & 171516 & 2.73 \\
\hline $\mathbf{N}_{\mathbf{4}} \mathbf{K}_{\mathbf{2}}$ & 126 & 63431 & 252171 & 188741 & 2.97 \\
\hline $\mathbf{N}_{\mathbf{4}} \mathbf{K}_{\mathbf{3}}$ & 161 & 64137 & 320973 & 256837 & 4.00 \\
\hline $\mathbf{N}_{\mathbf{4}} \mathbf{K}_{\mathbf{4}}$ & 165 & 63431 & 330799 & 267369 & 4.21 \\
\hline $\mathbf{N}_{\mathbf{4}} \mathbf{K}_{\mathbf{5}}$ & 167 & 64137 & 334909 & 270772 & 4.22 \\
\hline
\end{tabular}

Interaction effects of different nitrogen and potash levels

Data on economics as influenced by interaction effects between different levels of nitrogen and potash (Table-4) indicated that $125 \mathrm{~kg} \mathrm{~N} / \mathrm{ha}$ as well as $25 \mathrm{~kg} \mathrm{~K} \mathrm{~K}_{2} \mathrm{O} / \mathrm{ha}$ at basal $+25 \mathrm{~kg} \mathrm{~K} 2 \mathrm{O} / \mathrm{ha}$ at $45 \mathrm{DAS}$. $\left(\mathrm{N}_{3} \mathrm{~K}_{4}\right)$ recorded the highest $\mathrm{BCR}$ value 4.23 followed by treatment combination $\mathrm{N}_{4} \mathrm{~K}_{5}$, recorded the 4.22 BCR value. The lowest BCR value was noted under the treatment combination $\mathrm{N}_{1} \mathrm{~K}_{1}$ with 1.13. The higher $\mathrm{BCR}$ value under treatment combinations $\left(\mathrm{N}_{3} \mathrm{~K}_{4}\right)$ and $\mathrm{N}_{4} \mathrm{~K}_{5}$ was only due to higher green pod yield and lower total cost than other treatment combinations.

It is concluded that in light of the results obtained from this investigation, it is concluded that the application of $125 \mathrm{~kg} \mathrm{~N} / \mathrm{ha}$ along with $25 \mathrm{~kg} \mathrm{~K} \mathrm{~K}_{2} \mathrm{O} / \mathrm{haas}$ basal $+25 \mathrm{~kg}$ $\mathrm{K}_{2} \mathrm{O} /$ haat 45 DAS to kharif okra ( $c v$.Gujarat Anand Okra-5), produced higher green pod yield, quality, nutrient content and gave higher BCR value.

\section{References}

Cochran, W. G. and Cox, G. M. (1957). Experimental designs, John Willey and Sons. Inc., New York, 546-568.

Deepika, S. D., Hadimani, H. P., Ganiger, Vasant and Bhuvaneshwari, G. (2015). Response of nitrogen and phosphorus levels on the growth, yield and nutritional quality of okra. Green Farming, 6(5): 1010-1014.

Firoz, Z. A (2009). Impact of nitrogen and 
phosphorus on the growth and yield of okra (Abelmoschusesculentus L. Moench.) in hill slope condition. Bangladesh J. Agril. Res., 34(4): 713722.

Jackson, M.L. (1973). Soil Chemical Analysis, Indian edition. Prentice - Hall India Pvt. Ltd., New Delhi.

Khan, A., Shah, S. N., Rab, A., Sajid, M., Ali, K., Ahmed, A. and Faisal, S. (2014). Influence of nitrogen and potassium levels on growth and yield of chillies (Capsicum annum L.). International J.

Of Farming and Allied Sciences, 3(3): 260-264.

Mani, S. and Ramanathan, K. M. (1980). Effect of nitrogen and potassium on the yield of bhendi fruits. South Indian Horticulture, pp.136-138.

Mushtaq, F., Chattoo, M. A., Afroza, B., Amin, A., Mufti, s. and Nabi, A. (2014). Studies in relation to potassium application for improved growth and yield in chilli cv. Kashmir long-1. Green Farming, 5(6): 989-992.

Paliwal, R., Naruka, I. S. and Yadav, J. K. (1999). Effect of nitrogen and sulphur on growth and yield of okra (Abelmoschusesculentus L. Moench). Progressive Horticulture, 31 (1-2): 94-
97

Pushpavalli, R., Arulthasan, T. and Kandaswamy, K. G. (2014). Growth, nutrient uptake and yield of okra (Abelmoschus escilentus L. Moench) as influenced by organic and inorganic $\mathrm{K}$ fertilizers. Academia J. of Agric. Research, 2(10): 203-206.

Shanke, B. R., Jadao, B. J., Ghawade, S. M. and Mahorkar, V. K. (2003). Effect of different levels of $\mathrm{N}$ and $\mathrm{P}$ on growth and seed yield of okra (var. Parbhani Kranti), under Akola condition. Orissa J. Horti., 31(1): 123-124.

Singh, P. K., Singh, V. K., Singh, D. R., and Singh, P. N. (2012). Response of different levels of nitrogen, spacing and green fruit picking on growth, fruit yield, seed yield and seed quality of okra (Abelmoschus esculentus L. Moench). Ann. Agric. Res., 33 (1-2): 36-39.

Suthar, J. V., Patel, J. B., Patel, J. R., Doshi, J. S. and Patel, J. A. (2009). Effect of Organic Manures and Nitrogen levels on seed yield and seed quality of okra (Abelmoschus esculentusL. Moench) under Middle Gujarat Conditions. Seed Research, 37(1-2): 156-158.

\section{How to cite this article:}

Jaymin G. Chudhari, S.N. Shah, H. K. Patel and Shroff, J.C. 2020. Effect of Nitrogen and Potash Levels on Green Pod Yield, Quality and Post-harvest Soil Nutrient Status of Okra (Abelmoschus esculentus L. Moench) during kharif Season under Middle Gujarat Conditions. Int.J.Curr.Microbiol.App.Sci. 9(05): 1619-1626. doi: https://doi.org/10.20546/ijcmas.2020.905.183 